\title{
PENGARUH STRUKTUR MODAL, BIAYA EKUITAS, DAN KEBIJAKAN DIVIDEN \\ TERHADAP NILAI PERUSAHAAN PADA BADAN USAHA MILIK NEGARA (BUMN) YANG TERDAFTAR DI BURSA EFEK INDONESIA
}

\author{
Hendry Victory Supit \\ Herman karamoy \\ Jenny Morasa
}

(email: hendrysupit@yahoo.co.id)

\begin{abstract}
Source of corporate funding is essential to the operations of a firm. The problem that often arises is how companies choose the capital structure that could maximise the firm value but still pay attention to the wishes of investors and creditors to take advantage of the provision of funds through equity capital and debt capital.

The purpose of this paper is to examine the impact of capital structure, cost of equity, and dividend policy on the firm value at State Owned Enterprises (BUMN) that are listed in the Indonesia Stock Exchange.

The population in this study are all state-owned enterprises listed on the Indonesia Stock Exchange with a study period of 2009 to 2014, totaling 20 companies. Samples were selected using purposive sampling method amounted to 13 companies. The analytical method used multiple linear regression analysis and will be processed first with using classic assumption test. As for the processing of research data using SPSS version 23.0.

The test results simultaneously ( $\mathrm{F}$ test) the capital structure, the cost of equity, and dividend policy have impact on the firm value of state-owned companies in Indonesia. After the partial test ( $t$ test), capital structure has negative impact on the firm value, but the cost of equity and dividend policy concluded no impact on firm value.

Keywords: capital structure, cost of equity, and dividend policy
\end{abstract}

\section{PENDAHULUAN}

Pemerintah Indonesia melakukan berbagai upaya untuk meningkatkan Pendapatan Negara.Anggaran Pendapatan dan Belanja Negara Tahun Anggaran 2015menurut UU No. 3 Tahun 2015 tercatat bahwa total anggaran pendapatan negara tahun 2015 sebesar Rp 1.761 triliun. Sumber pendapatan negara tersebut berasal dari tiga sektor utama yaitu: penerimaan perpajakan, penerimaan negara bukan pajak, dan penerimaan hibah. Penerimaan perpajakan diperkirakan sebesar Rp 1.489 triliun, penerimaan negara bukan pajak diperkirakan sebesar Rp 269 triliun, dan penerimaan hibah diperkirakan sebesar Rp 3,3 triliun. Dari berbagai sumber pendapatan negara tersebut, terdapat 'pendapatan bagian laba' dari Badan Usaha Milik Negara (BUMN).

BUMN adalah badan usaha yang seluruh atau sebagian besar modalnya dimiliki oleh negara melalui penyertaan secara langsung yang berasal dari kekayaan negara yang dipisahkan (Undang-Undang Nomor 19 Tahun 2003).Tercatat dalam situs resmi kementerian BUMN yakni bumn.go.id, sampai pada bulan September 2015 yang terdaftar sebanyak 119 BUMN. Namun, dari 119 BUMN hanya 20 (16,8\%) yang go public atau terdaftar di Bursa Efek Indonesia (BEI). Hal ini menjadi perhatian dari berbagai pihak seperti Otoritas Jasa Keuangan (OJK) yang merasa prihatin akan rendahnya jumlah perusahaan BUMN yang melantai di BEI.

Sesuai dengan definisi BUMN, dapat dipahami bahwa pemerintah mempunyai kepemilikan atau saham lebih dari 50\%.Hal ini terbukti berdasarkan data yang dihimpun dari BEI pada awal tahun 2015, Negara Republik Indonesia mempunyai kepemilikan saham lebih dari 50\% untuk semua saham BUMN. Kepemilikan saham paling kecil yakni sebesar 51\% pada Adhi Karya (Persero) Tbk. dan PP (Persero) Tbk., sedangkan kepemilikan terbesar yakni pada Kimia Farma (Persero) Tbk. yang mencapai 90,03\%. Jika dihitung rata-rata kepemilikan Negara Republik Indonesia atas saham 20 perusahaan BUMN yang 
melantai di BEI yakni sebesar 64,15\%. Dari 20 perusahaan BUMN yang terdaftar di BEI sesuai data akhir tahun 2014 memiliki kapitalisasi pasar modal sebesar 26,41\% dari seluruh saham yang tercatat.

BEI mengelompokkan 10 sektor berdasarkan jenis usahanya yaitu: (a) pertanian (agriculture), (b) pertambangan (mining), (c) industri dasar (basicindustryandchemicals), (d) aneka industri (miscellaneousindustry), (e) barang konsumsi (consumergoodsindustry), (f) properti (property, real estate and building construction), (g) infrastruktur (infrastructure, utilities and transportation), (h) keuangan (finance), (i) perdagangan dan jasa (trade, service, andinvestment), (j) manufaktur (manufacturing). Dari 10 sektor tersebut, hanya enam sektor yang diisi oleh perusahaan BUMN.Enam sektor yang diisi oleh perusahaan BUMN dengan alokasi empat perusahaan masing-masing untuk sektor properti, infrastruktur, dan keuangan.Tiga perusahaan masing-masing untuk sektor pertambangan, dan industri dasar.Dua perusahaan untuk sektor barang konsumsi.Dari 20 perusahaan BUMN inilah pemerintah menerima pendapatan untuk negara berupa dividen.

Pendapatan dividen pemerintah dari BUMN sejak tahun 2011 sampai 2014 mengalami peningkatan. Pada tahun 2011 pemerintah menerima dividen sebesar Rp 28,20 triliun, pada tahun 2012 sebesar Rp 30,78 triliun, pada tahun 2013 sebesar 34,02 triliun, dan pada tahun 2014 sebesar Rp 40,16 triliun. Penerimaan dividen yang semakin besar tersebut menunjukkan kinerja BUMN semakin baik namun di sisi lain dinilai bahwa pemberian dividen yang tinggi dapat mengganggu perkembangan usaha. Pemberian dividen yang tinggi dapat menyebabkan perusahaan kehilangan dana untuk membiayai rencana perusahaan seperti ekspansi maupun investasi yang mungkin sudah ditetapkan sebelumnya. Selain itu, memungkinkan perusahaan mencari dana dari pihak luar berupa pinjaman yang berisiko menurunkan kinerja perusahaan

Pemberian dividen melalui berbagai penelitan terdahulu pada umumnya memberikan pengaruh terhadap nilai perusahaan.Efendi (2013) membuktikan bahwa kebijakan dividen berpengaruh positif terhadap nilai perusahaan. Pemberian dividen yang tercermin dari dividend payout ratio melalui penelitian tersebut pada umumnya menunjukkan semakin besar dividen yang diberikan oleh perusahaan, minat investor untuk memiliki saham tersebut akan semakin besar yang tentunya akan mempengaruhi harga saham. Perubahan pada harga saham tersebut tentunya berpengaruh langsung terhadap nilai perusahaan, sehinggan secara tidak langsung mempengaruhi penilaian dari investor dan kreditor sebagai sumber pendanaan perusahaan.

Sumber pendanaan atau sering disebut struktur modal perusahaan dapat dilihat pada Laporan Keuangan Neraca untuk bagian Kewajiban dan Modal.Sumber danainternal perusahaan biasanya berasal dari pemilik perusahaan dan laba ditahan. Sumber dana eksternal perusahaan bisa berasal dari kreditur. Pendanaan yang berasal dari para kreditur merupakan hutang bagi perusahaan sedangkandana yang diperoleh dari para pemilik perusahaan merupakan modal sendiri. Menurut Helfert dalam Elfrida (2008) menyatakan bahwa struktur modal dapat menggunakan perhitungan Debt to Equity Ratio (DER) yang menunjukkan perbandingan antara total utang dan total modal yang dimiliki perusahaan.

Hasil perhitungan pada laporan keuangan tahun 2014 untuk 20 BUMN yang tercatat di BEI, ditemui bahwa nilai DER dari perusahaan-perusahaan tersebut memiliki perbedaan yang dipengaruhi oleh sektor masing-masing. Diantara 6 sektor, BUMN sektor keuangan memiliki rata-rata nilai DER yang paling tinggi yakni 7,7. DER yang tinggi ini dikarenakan perusahaan sektor keuangan dalam hal ini keempat perusahan BUMN tersebut tergolong dalam sub sektor perbankan. Ini disebabkan karena sebagian besar dana yang dikelolanya berasal dari pihak luar perusahaan ataupun nasabah yang kemudian secara akuntansi dicatat sebagai hutang (liabilities). Berdasarkan laporan keuangan tersebut nilai DER berturut-turut setelah sektor keuangan yaitu, sektor properti 3,92, sektor infrastruktur 1,48, sektor barang konsumsi 0,88, sektor industri dasar 0,79, dan paling kecil yakni sektor pertambangan dengan nilai 0,77. Secara keseluruhan, rata-rata nilai DER untuk 20 perusahaan BUMN berdasarkan laporan keuangan tahun 2014 yakni 2,59. Hal ini menunjukkan bahwa sumber pendanaan perusahaan BUMN yang tercatat di BEI sebagian besar berasal dari pihak luar perusahaan.

Berdasarkan rasio DER diatas juga didukung oleh data Statistik Utang Luar Negeri Indonesia (SULNI) yang dipublikasikan oleh Bank Indonesia (BI) didapati bahwa utang luar negeri dari perusahaan BUMN cenderung meningkat dari tahun ke tahun. Pada tahun 2010 utang luar negeri perusahaan BUMN sebesar 8,53 miliar dollar AS dan melonjak 289,13\% menjadi 24,67 miliar dollar AS pada akhir tahun 
2013. Selanjutnya berdasarkan angka sementara pada akhir tahun 2014 utang luar negeri perusahaan BUMN kembali naik menjadi 30,72 miliar dollar AS. Tren kenaikan yang cukup signifikan tersebut yang mungkin menjadi salah satu pertimbangan dari pemerintah untuk menambah Penyertaan Modal Negara untuk APBN tahun 2015 ini.

Penyertaan Modal Negara (PMN) berdasarkan Peraturan Pemerintah No.44 Tahun 2005 memiliki definisi yaitu pemisahan kekayaan negara dari Anggaran Pendapatan dan Belanja Negara atau penetapan cadangan perusahan atau sumber lain untuk dijadikan sebagai modal BUMN dan/atau Perseroan Terbatas lainnya, dan dikelola secara korporasi. PMN untuk APBN 2015 ini naik signifikan dibanding dengan tahun-tahun sebelumnya. Untuk tahun 2014 PMN sebesar Rp 5,3 triliun dan berdasarkan APBN-P 2015 yang sudah disetujui melonjak tajam menjadi Rp 64,8 triliun. Pemberian PMN ini menjadi pro kontra dari berbagai kalangan.Banyak kalangan yang tidak menyetujui karena dirasa angkanya terlalu besar sehingga rawan penyimpangan namun ada juga yang optimis bahwa pemberian PMN dapat mendongkrak kinerja dari BUMN penerima. Sebagian kalangan meyakini bahwa angka ini dapat mengurangi ketergantungan sumber dana dari pihak luar perusahaan yang dapat menghambat tujuan perusahaan dalam jangka panjang yaitu mengoptimalkan nilai perusahaan dengan meminimumkan biaya ekuitas perusahaan.

Semakin tinggi nilai perusahaan menggambarkan semakin sejahtera pemilik perusahaan atau investor. Investor mengharapkan imbal balik dalam kegiatan investasinya yaitu berupa dividen dan capital gain sedangkan dari sudut pandang perusahaan masuk dalam biaya ekuitas, hal ini menyebabkan perbedaan kepentingan antara perusahaan dan investor.Perbedaan kepentingan tersebut dapat menghambat terciptanya informasi yang baik sehingga muncul risiko investasi.

Lambert et al, dalam Kirana (2013) menyatakan bahwa informasi yang baik akan menyebabkan rendahnya cost of equity capital karena adanya keselarasan yang baik antara peluang investasi perusahaan dan investasi pilihan. Semakin baik informasi yang disampaikan maka semakin kecil tingkat risiko yang dihasilkan. Logikanya ialah informasi yang baik akan mengurangi asimetri informasi. Hal ini sesuai dengan prinsip umum yang sering disampaikan dalam pasar modal yakni high risk - high return. Dengan demikian menunjukkan hubungan antara biaya ekuitas perusahaan dengan nilai perusahaan dimata investor.

Berdasarkan uraian yang dipaparkan diatas dapat dilihat bahwa nilai perusahaan dapat dipengaruhi oleh berbagai faktor. Faktor-faktor tersebut antara lain sumber pendanaan perusahaan (struktur modal), biaya ekuitas, dan pemberian dividen kepada pemegang saham. Oleh karena itu penulis menarik judul dalam penelitian ini yaitu "Pengaruh Struktur Modal, Biaya Ekuitas, dan Kebijakan Dividen terhadap Nilai Perusahaan pada Badan Usaha Milik Negara (BUMN) yang terdaftar di Bursa Efek Indonesia."

Rumusan masalah pada penelitian ini yaitu: "Apakah struktur modal, biaya ekuitas (cost of equity),dan kebijakan dividen berpengaruh terhadap nilai perusahaan BUMN di Bursa Efek Indonesia?".

\section{LANDASAN TEORI}

\section{Struktur Modal}

Ada beberapa pengertian struktur modal yang dikutip dalam Fahmi (2011:106). Menurut Weston dan Copeland bahwa capital structure or the capitalization of the firm is the permanent financing represented by long-term debt, preferred stock and shareholder's equity. Sedangkan Joel G. Siegel dan Jae K. Shim mengatakan Capital Structureadalah komposisi saham biasa, saham preferen, dan berbagai kelas seperti itu, laba yang ditahan, dan utang jangka panjang yang dipertahankan oleh kesatuan usaha dalam mendanai aktiva.

Menurut Subramanyam \& Wild (2010:262), struktur modal mengacu pada sumber pendanaan perusahaan. Struktur modal merupakan pendanaan ekuitas dan utang pada suatu perusahaan yang sering dihitung berdasarkan besaran relatif berbagai sumber pendanaan. Parrino dkk (2012) menyatakan bahwa the mix of debt and equity on the balance sheet is known as a firm 's capital structure.

Struktur modal secara garis besar dapat dibedakan menjadi dua yaitu:Simple Capital Structure, yaitu jika perusahaan hanya menggunakn modal sendiri saja dalam struktur modalnya dan Compex Capital Structure, yaitu jika perusahaan tidak hanya menggunakan modal sendiri tetapi juga menggunakan modal pinjaman dalam struktur modalnya (Fahmi, 2011: 107) 
Rasio struktur modal merupakan salah satu alat analisis solvabilitas.Rasio komprehensif tersedia untuk mengukur hubungan antara total utang (utang lancar + utang jangka panjang + kewajiban lainnya yang ditentukan oleh analisis seperti pajak tangguhan dan saham preferen yang dapat ditarik kembali) dengan total modal (total utang + ekuitas pemegang saham termasuk saham preferen).

Teori modern struktur modal bermula dengan publikasi Modigliani dan Miller (1958) yang menunjukkan bahwa, jika investor dapat meminjam dan menghemat pada saat yang sama, dan jika keputusan pendanaan perusahaan tidak mempengaruhi total arus kas, maka pilihan perusahaan antara utang dan ekuitas tidak memiliki pengaruh pada total nilai pasar mereka. Dengan kata lain, struktur modal tidak bisa menciptakan nilai kecuali itu mempengaruhi total returns. Kesimpulan ini berdasarkanpada asumsi bahwa pasar modal yang sempurna, dan bahwa tidak ada pajak. Selain itu, jelas bahwa dalam kenyataannya perusahaan memiliki struktur modal yang sangat berbeda.Model MM dengan demikian harus dilihat sebagai titik awal untuk pemodelan skenario yang lebih realistis yang menjelaskan mengapa utang dapat digunakan dalam preferensi ekuitas.

Sejak akhir 1970-an, ada dua penelitian baru mengenai teori perusahaan: 'pecking order theory'dan 'trade-off theory (balancing theory)'. Teori pecking order menyatakan bahwa perusahaan memiliki preferensi menerbitkan instrumen pendanaan. Teori ini menunjukkan bahwa manajer keuangan cenderung menggunakan modal internal sebagai pilihan pertama, kemudian mengeluarkan utang, dan kemudian ekuitas hanya akan dipertimbangkan sebagai pilihan terakhir dimana penerbitan ekuitas dapat dirasakan oleh pasar sebagai sinyal yang buruk untuk investasi. Sebaliknya, trade-off teori menekankan bahwa struktur modal yang optimal dapat dicapai dengan trade-off(pertukaran) dari berbagai manfaat dari hutang dan ekuitas.(Chen, 2005)

\section{Biaya Ekuitas}

Biaya ekuitas dapat menurut Van Horne \& Wachowicz (2008) yaitu, the required rate of return on investment of the common shareholders of the company. Sedangkan menurut Dhankar dan Bora dalam Nasution (2009), biaya ekuitas merupakan biaya yang dikeluarkan oleh perusahaan yangmemperoleh dana dengan menjual saham biasa atau menggunakan laba yang ditahanuntuk investasi. Sesuai Keputusan Ketua Badan Pengawas Pasar Modal dan LembagaKeuangan Nomor: KEP-196/BL/2012 tentang PedomanPenilaian dan Penyajian Laporan Penilaian Usaha di Pasar Modal diketahui bahwa biaya ekuitas untuk saham diantaranya dapat dihitung dengan model Capital Asset Pricing Model (CAPM). CAPM adalah sebuah model hubungan antara risiko dan expected return suatu sekuritas atau portofolio. Model tersebut dapat digunakan untuk menentukan harga aset berisiko. Menurut CAPM, risiko yang dinilai oleh investor yang rasional hanya systematic risk karena risiko tersebut tidak bisa dihilangkan dengan diversifikasi. Model tersebut menyatakan bahwa expected return sebuah sekuritas atau portofolio sama dengan return sekuritas bebas risiko ditambah dengan risk premium dikalikan dengan systematic risk sekuritas tersebut.

\section{Kebijakan Dividen}

Dalam Bernandhi (2013) kebijakan dividen merupakan keputusan yang terkait dengan pertanyaan apakah laba yang diperoleh perusahaan akan dibagikan kepada pemegang saham atau akan digunakan untuk menambah modal dalam rangka pembiayaan investasi di masa depan. Rasio pembayaran dividen atau dividend payout ratio (DPR) menjadi penentu berapa bagian jumlah laba yang dibagikan dalam bentuk dividen kas dan laba ditahan sebagai sumber pendanaan.

Terdapat beberapa pendapat dan teori yang mengemukakan tentang dividen diantaranya yaitu (Brigham, 2004 dalam Ellisya, 2013):Dividend Irrelevance Theory (ketidakrelevanan dividen),teori yang menyatakan bahwa kebijakan dividen perusahaan tidak mempunyai pengaruh terhadap nilai perusahaan maupun biaya modalnya. Peningkatan pembayaran dividen hanya dimungkinkan apabila laba yang diperoleh perusahaan juga meningkat. Keuntungan yang diperoleh atas kenaikan harga saham akibat pembayaran dividen akan diimbangi dengan penurunan harga saham karena adanya penjualan saham baru. Oleh karenanya pemegang saham dapat menerima kas dari perusahaan saat ini dalam bentuk pembayaran dividen atau menerimanya dalam bentuk capital gain.Kemakmuran pemegang saham sekali lagi tidak dipengaruhi oleh kebijakan dividen saat ini maupun dimasa datang. 
The Bird in Hand Theory.Teori ini sependapat dengan Gordon dan Lintner (1992) yang berpendapat bahwa investor lebih merasa aman untuk memperoleh pendapatan berupa pembayaran dividen daripada menunggu capital gain.

Tax Preferance Theory. Teori ini menyatakan bahwa Investor menghendaki perusahaan untuk menahan laba setelah pajak dan dipergunakan untuk pembiayaan investasi dari pada dividen dalam bentuk kas.Oleh karenanya perusahaan sebaiknya menentukan dividen payout ratio yang rendah atau bahkan tidak membagikan dividen. Karena dividen cenderung dikenakan pajak yang lebih tinggi dari pada capital gain, maka investor akan meminta tingkat keuntungan yang lebih tinggi untuk saham dengan dividen yield yang tinggi.

\section{Nilai Perusahaan}

Pengertian nilai perusahaan menurut Suad Hasnan dalam Jusriani (2013), nilai perusahaan merupakan harga yang bersedia dibayar oleh calon pembeli apabila perusahaan tersebut dijual. Menurut Keown dalam Efendi (2013), nilai perusahaan merupakan nilai pasar atas surat berharga hutang dan ekuitas perusahaan yang beredar. Sedangkan menurut Maurice, Thomas dalam Jusriani (2013) menyatakan bahwa "Value of the firm is the price for which the firm can be sold, which equals the present of future profits."

Christiawan dan Tarigan (2007) menyimpulkan bahwa konsep yang paling representatif untuk menentukan nilai perusahaan adalah pendekatan konsep nilai intrinsik.Tetapi memperkirakan nilai intrinsik sangat sulit, sebab untuk menentukannya orang membutuhkan kemampuan mengidentifikasi variabel-variabel signifikan yang menentukan keuntungan suatu perusahaan.variabel itu berbeda dari satu perusahaan ke perusahaan yang lain. Selain itu, penentuan nilai intrinsik juga memerlukan kemampuan memprediksi arah kecenderungan yang akan terjadi di kemudian hari. Karena itulah, maka nilai pasar digunakan dengan alasan kemudahan data juga didasarkan pada penilaian yang moderat.Menurut Ahmed dan Nanda dalam Efendi (2013), nilai perusahaan sering diproksikan dengan price to book value.Price to book value atau juga sering disebut market to book ratio dapat diartikan sebagai perbandingan antara harga saham dengan nilai buku per lembar saham.

\section{Penelitian Terdahulu}

Penelitian yang dilakukan Patrick, Orinya, dan Kemi (2013) dengan judul The Impact of Capital Structure on Firms' Performance in Nigeria menemukan adanya hubungan negatif yang signifikan antara leverage dengan performa perusahaan. Dalam penelitiannya, mereka juga menemukan bahwa teori struktur modal tradisional itu benar (valid). Setiap kenaikan 1\% leverage akan menurunkan performa perusahaan sebesar $15,8 \%$. Penelitian ini menggunakan variabel-variabel berikut: Return on Investment (ROI) sebagai variabel atas Firm Performance (dependen) serta Leverage \& Inflation (independen). Periode penelitian ini yakni dari tahun 2000 sampai 2010 pada perusahaan-perusahaan di Nigeria.

Nababan (2015) meneliti dengan judul Analisis Pengaruh Struktur Modal dan Kebijakan Dividen terhadap Nilai Perusahaan (Studi pada Saham-saham LQ 45 di Bursa Efek Indonesia Periode 20082014).Dalam penelitian ini yang menjadi variabel independen yaitu Struktur Modal dan Kebijakan Dividen sedangkan yang menjadi variabel dependen yakni Nilai Perusahaan.Analisis data menggunakan analisis regresi berganda.Hasil penelitian menunjukkan bahwa selama periode 2008-2014 secara parsial struktur modal berpengaruh positif dan tidak signifikan terhadap nilai perusahaan.Variabel kebijakan dividen berpengaruh positif dan signifikan terhadap nilai perusahaan. Sedangkan secara simultan menunjukkan bahwa besarnya kemampuan prediksi dari kedua variabel independen terhadap nilai perusahaan adalah sebesar $25,5 \%$, sisanya sebesar 74,5\% dipengaruhi oleh variabel lain diluar penelitian atau persamaan regresi.

Nasution (2009) melakukan penelitian dengan judul Pengaruh Struktur Modal, Biaya Ekuitas, dan Pertumbuhan Perusahaan terhadap Nilai Perusahaan dengan Klasifikasi Perusahaan dan Kepemilikan Asing sebagai variabel moderating pada perusahaan lembaga keuangan yang terdaftar di BEI. Dalam penelitian ini yang menjadi variabel independen yaitu struktur modal dan biaya ekuitas, variabel moderating yaitu klasifikasi perusahaan dan kepemilikan asing, serta variabel dependen yaitu nilai perusahaan.Analisis data menggunakan regresi linier berganda dengan metode backward dan uji interaksi 
variabel moderating untuk menguji secara parsial dan simultan, dengan tingkat signifikansi alpha 5\%.Hasil peneltiain membuktikan bahwa struktur modal berpengaruh secara positif dan signifikan terhadap nilai perusahaan, biaya ekuitas berpengaruh positif tetapi tidak signifikan terhadap nilai perusahaan dan pertumbuhan perusahaan berpengaruh positif tetapi tidak signifikan terhadap nilai perushaaan.Secara simultan membuktika nbahwa struktur modal, biaya ekuitas dan pertumbuhan perusahaan berpengaruh secara positif dang signifikan terhadap nilai perusahaan.

\section{KERANGKA KONSEPTUAL}

Parrino et. al (2012) menyatakan bahwa the optimal capital structure for a firm is the capital structure that minimizes the overall cost of financing the firm's portfolio of projects. Minimizing the overall cost of financing the firm's projects maximizes the value of the firm's free cash flows. Sedangkandalam Brigham \& Houston (2007), a firms optimal capital structure is defined as the structure that would maximize its stock price. Pendapat diatasmendukung trade off theory yang menyatakan bahwa terdapat struktur modal optimal yang bisa memaksimalkan nilai perusahaan

Struktur modal bertujuan memadukan sumber dana permanen yang selanjutnya digunakan perusahaan dengan cara yang diharapkan akan mampu memaksimumkan nilai perusahaan. Bagi sebuah perusahaan sangat dirasa penting untuk memperkuat kestabilan keuangan yang dimilikinya, karena perubahan dalam struktur modal diduga bisa menyebabkan perubahan nilai perusahaan.Turunnya nilai perusahaan bisa mempengaruhi pada turunnya nilai saham perusahaan tersebut.Nilai perusahaan diperoleh dari hasil kualitas kinerja suatu perusahaan khususnya kinerja keuangan (financial performance), tentunya tidak bisa dikesampingkan dengan adanya dukungan dari kinerja non keuangan juga, sebagai sebuah sinergi yang saling mendukung membentuk nilai perusahaan.(Fahmi, 2011)

Menurut Prihadi (2013), biaya ekuitas (cost of equity)mencerminkan tingkat hasil yang dituntut pemegang saham. Untuk perusahaan publik yang sahamnya diperdagangkan di pasar modal maka biaya ekuitasnya dapat dihitung dengan data yang tersedia.Pergerakan saham merupakan indikator seberapa besar harapan investor terhadap investasinya di saham tersebut.Bagi emiten hal tersebut merupaka indikator biaya ekuitas. Oleh karena itu biaya ekuitas dapat dikaitkan dengan pergerakan harga saham.

Biaya ekuitas dinilai dapat mempengaruhi nilai perusahaan hal ini diperkuat pernyataan Brigham dan Houston (2007) yang menuliskan bahwa, higher debt levels also increase the firm's risk, and the raises the cost of equity and works to reduce the stock price. Even though increasing the debt ratio from 40 to 50 percent raises Earning per Share (EPS), the higher EPS is more than ofset by the corresponding increase in risk. Berdasarkan pernyatan diatas dapat diambil kesimpulan bahwa hutang, tingkat risiko, dan biaya ekuitas bisa menurunkan harga saham sehingga sesuai penelitian ini mempengaruhi MBR sebagai rasio pengukuran dari nilai perusahaan.Hal ini sesuai dengan hasil penelitian Nasution (2009) yang menunjukkan hasil bahwa secara parsial biaya ekuitas berpengaruh positif terhadap nilai perusahaan.

Terdapat beberapa pendapat yang menghubungkan kebijakan dividen dengan nilai perusahaan. Dalam Bernandhi (2013), Modigliani dan Miller berpendapat bahwa kebijakan dividen tidaklah relevan (dividend irrelevance theory), hal ini berarti bahwa tidak ada kebijakan dividen yang optimal karena tidak ada pengaruhnya terhadap nilai perusahaan. Pendapat kedua oleh Gordon-Lintner yang menyatakan bahwa risiko dividen lebih kecil daripada capital gain.Pernyataan ini kemudian biasa disebut sebagai teori bird in the hand.Karena risiko dividen yang kecil tersebut maka peruahaan seharusnya memperbesar nilai rasio pembayaran dviden untuk meningkatkan harga sahamnya yang kemudian berdampak pada naiknya nilai perusahaan.Perbedaan pandangan dari berbagai ahli sering timbul terhadap masalah pemberian dividen dalam rangka meningkatkan nilai perusahaan sehinga timbul berbagai penelitian setelahnya.

\section{METODE PENELITIAN}

Sesuai dengan tujuan penelitian yaitu menguji hipotesis, maka desain penelitian yang digunakan dalam penelitian ini adalah desain kausal. Desain kausal berguna untuk menganalisis hubungan-hubungan antara satu variabel dengan variabel lainnya atau bagaimana suatu variabel mempengaruhi variabel lainnya. 
Penentuan populasi dalam penelitian ini yaitu seluruh perusahaan yang tercatat di BEI dan merupakan perusahaan Badan Usaha Milik Negara (BUMN) dengan jumlah20 perusahaan

Penentuan sampel dalam penelitian ini berdasarkan pada metode purposive sampling, di mana sampel perusahaan dipilih berdasarkan pada kriteria tertentu. Adapun kriteria yang digunakan untuk memilih sampel yaitu sebagai berikut: (1) Perusahaan BUMN yang terdaftar di Bursa Efek Indonesia.(2) Perusahaan BUMN yang menerbitkansecara berturut-turut Laporan Keuangan dari tahun 2009-2014 di Bursa Efek Indonesia.(3) Perusahaan BUMN yang memberikan dividen secara rutin dari tahun 20092014 di Bursa Efek Indonesia.

Variabel Nilai Perusahaan (Y) diukur dengan Market to Book Ratio (MBR).Market to Book Ratio adalah perbandingan antara harga pasar perlembar saham terhadap nilai buku ekuitas perlembar saham, yang dalam penelitian ini pada perusahaan BUMN tahun 2009-2014.Variabel Struktur Modal $\left(\mathrm{X}_{1}\right)$. Struktur Modal diukur dengan Debt to Equity Ratio (DER), merupakan perbandingan total hutang yang dimiliki perusahaan terhadap total ekuitas perusahaan BUMN tahun 2009-2014.Variabel Biaya Ekuitas $\left(\mathrm{X}_{2}\right)$.Estimasi biaya ekuitas dilakukan dengan menggunakan pendekatan Capital Asset Pricing Model $(\mathrm{CAPM})$ dengan rumus $\mathrm{CAPM}=\mathrm{Rf}+\beta(\mathrm{Rm}-\mathrm{Rf})$. Variabel Kebijakan Dividen $\left(\mathrm{X}_{2}\right)$. Variabel kebijakan dividen diukur dengan Dividend Payout Ratio (DPR), yang merupakan perbandingan antara jumlah dividen yang dibayarkan per lembar saham dan jumlah laba yang dibayarkan per lembar saham

Lokasi penelitian ini adalah pada Bursa Efek Indonesia. Sedangkan waktu penelitian ini yakni periode tahun 2009-2014.

Teknik analisis data yang dilakukan dalam penelitian ini adalah menggunakan model model regresi linear berganda Untuk dapat melakukan analisis dengan model regresi, data harus good and fit. Penilaian good and fit dianalisis dengan uji kualitas data. Adapun uji kualitas data terdiri dari statistik deskriptif dan asumsi klasik yang terdiri dari uji normalitas, uji autokorelasi, uji multikolinearitas dan uji heterokedasitas.Pengujian hipotesis dalam penelitian menggunakan alat stastitik SPSS versi 23

Persamaan regresi untuk mengetahui pengaruh struktur modal, biaya ekuitas dan pertumbuhan perusahaan terhadap nilai perusahaan disusun sebagai berikut :

$$
\mathrm{Y}=\mathrm{a}+\beta_{1} \mathrm{X}_{1}+\beta_{2} \mathrm{X}_{2}+\beta_{3} \mathrm{X}_{3}++\varepsilon
$$

Dimana: $Y=$ Nilai Perusahaan

$\mathrm{X}_{1}=$ Struktur Modal

$\mathrm{X}_{2}=$ Biaya Ekuitas

$\mathrm{X}_{3}=$ Kebijakan Dividen

$\mathrm{a}=$ Konstanta

$\varepsilon=$ Error

$\beta=$ Koefisien Regresi

\section{ANALISIS DAN PEMBAHASAN HASIL PENELITIAN \\ Hasil Penelitian}

Hasil statistik deskriptif dari masing-masing variabel yaitu nilai perusahaan, struktur modal, biaya ekuitas dan kebijakan dividen adalah sebagai berikut:Rata-rata nilai perusahaan dengan jumlah data 78 adalah sebesar 2,5012 dengan standar deviasi 1,44642.Rata-rata struktur modal dengan jumlah data 78 adalah sebesar 3,6291dengan standar deviasi 3,66880. Rata-rata biaya ekuitas dengan jumlah data 78 adalah sebesar 4,4788 dengan standar deviasi 1,19510Rata-rata arus kas dengan jumlah data 56 adalah sebesar 0,33644 dengan standar deviasi 0,14497.

Untuk mengetahui data berdistribusi secara normal dilakukan uji Normality P-Plot dimana terlihat bahwa data (titik-titik) menyebar di sekitar garis diagonal dan penyebarannya mengikuti arah garis diagonal tersebu.Pengujian normalitas data juga secara statistik dapat dilakukan dengan menggunakan Uji Kolmogorov - Smirnov.Dari hasil pengujian tersebut menunjukkan bahwa data telahterdistribusi secara normal.Uji Multikolineraritas digunakan untuk mengetahui apakah terjadi korelasi yang kuat di antara variabel-variabel independen yang diikutsertakan dalam pembentukan model. Berdasarkan output pengujian variabel struktur modal, biaya ekuitas, dankebijakan dividen dikatakan tidak terdapat multikolinieritas.Uji heterokedastisitas dalam penelitian ini dilakukan dengan melihat grafik scatterplot 
antara nilai residu variabel dependen SRESID dengan nilai prediksi variabel independen ZPRED.Berdasarkan grafik plot antara nilai prediksi variabel terikat dengan residualnya diperoleh hasil tidak adanya pola yang jelas, serta titik-titik menyebar diatas dan dibawah angka 0 (nol) pada sumbu Y, maka tidak terjadi Heteroskedastisitas. Untuk pengujian autokorelasi digunakan metode run test. Dari hasil pengujian runs test, maka diperoleh hasil 0,648>0,05. Hal ini berarti bahwa data tidak mengalami atau mengandung autokorelasi.

Hasil pengujian hipotesis dapat dilihat pada tabel berikut ini:

\section{Model Summary ${ }^{\mathrm{b}}$}

\begin{tabular}{|l|c|r|r|r|}
\hline Model & R & R Square & $\begin{array}{c}\text { Adjusted R } \\
\text { Square }\end{array}$ & $\begin{array}{c}\text { Std. Error of } \\
\text { the Estimate }\end{array}$ \\
\hline 1 & $.364^{\mathrm{a}}$ & .132 & .097 & 1.37438 \\
\hline
\end{tabular}

a. Predictors: (Constant), KEBIJAKAN DIVIDEN,

BIAYA EKUITAS, STRUKTUR MODAL

b. Dependent Variable: NILAI PERUSAHAAN

Angka R Square yaitu 0,132 merupakan angka pengkuadratan dari koefisien korelasi atau $(0.364)^{2}=$ 0,132. Angka tersebut berarti 13,2\% nilai perusahaan dapat dijelaskan oleh variabel struktur modal, biaya ekuitas, dan kebijakan dividen. Sedangkan sisanya disebabkan oleh faktor-faktor lain.

Uji F dilakukan untuk mengetahui apakah variabel-variabel independen yaitu Struktur Modal $\left(\mathrm{X}_{1}\right)$,Biaya Ekuitas $\left(\mathrm{X}_{2}\right)$,dan Kebijakan Dividen $\left(\mathrm{X}_{3}\right)$ secara bersama-sama (simultan) mempunyai pengaruh terhadap variabel dependen yaitu Nilai Perusahaan (Y). Berikut tabel hasil uji simultan:

\begin{tabular}{|ll|r|r|r|r|r|}
\hline \multicolumn{1}{|c|}{ ANOVA $^{\mathrm{a}}$} & \multicolumn{1}{l|}{} \\
\hline 1 & & Sum of Squares & $\mathrm{df}$ & Mean Square & F & Sig. \\
\hline & Regression & 21.315 & 3 & 7.105 & 3.761 & $.014^{\mathrm{b}}$ \\
& Residual & 139.780 & 74 & 1.889 & & \\
& Total & 161.095 & 77 & & & \\
\hline
\end{tabular}

a. Dependent Variable: NILAI PERUSAHAAN

b. Predictors: (Constant), KEBIJAKAN DIVIDEN, BIAYA EKUITAS, STRUKTUR MODAL

Dari hasil perhitungan pengujian yang dilakukan (Uji F) dapat dilihat variabel independen yang mempunyai pengaruh yang signifikan terhadap variabel dependen. Hal ini didasarkan pada perbandingan $F_{\text {hitung }}$ dengan $F_{\text {tabel }}$ dan signifikansi hitung berada di angka 0,05 . Berdasarkan hasil pengujian statistik Uji Simultan $(\mathrm{Uji} F) \mathrm{F}_{\text {hitung }}$ diperoleh angka 3,761 $>$ dari $\mathrm{F}_{\text {tabel }} 2,73$ dan sig. hitung 0,014<0,05 ( $\alpha$ : 5\%)sehingga $\mathrm{H}_{1}$ diterima. Hal ini berarti bahwa Struktur Modal, Biaya Ekuitas, dan Kebijakan Dividen secara simultan mempunyai pengaruh yang signifikan terhadap nilai perusahaan BUMN periode 2009 - 2014.

Setelah melakukan uji F, maka selanjutnya dilakukan uji statistik (uji t).Uji statistik (uji t) dilakukan untuk mengetahui pengaruh variabel independen secara individual (statistik) terhadap variabel dependen. Pada tabel di bawah ini akan disajikan hasil regresi linier berganda :

Coefficients $^{\mathrm{a}}$

\begin{tabular}{|c|c|c|c|c|c|c|}
\hline \multirow{2}{*}{\multicolumn{2}{|c|}{ Model }} & \multicolumn{2}{|c|}{ Unstandardized Coefficients } & \multirow{2}{*}{$\begin{array}{c}\begin{array}{c}\text { Standardized } \\
\text { Coefficients }\end{array} \\
\text { Beta }\end{array}$} & \multirow[b]{2}{*}{$t$} & \multirow[b]{2}{*}{ Sig. } \\
\hline & & $\mathrm{B}$ & Std. Error & & & \\
\hline \multirow[t]{4}{*}{1} & (Constant) & 3.604 & .991 & & 3.635 & .001 \\
\hline & STRUKTUR MODAL & -.140 & .056 & -.354 & -2.506 & .014 \\
\hline & BIAYA EKUITAS & -.138 & .134 & -.114 & -1.030 & .306 \\
\hline & KEBIJAKAN DIVIDEN & .064 & 1.405 & .006 & .045 & .964 \\
\hline
\end{tabular}

a. Dependent Variable: NILAI PERUSAHAAN

Dari hasil perhitungan pengujian yang dilakukan (Uji t) dapat dilihat variabel independen yang mempunyai pengaruh terhadap variabel dependen adalah variabelStruktur Modal yaitu bersasarkan perbandingan $t_{\text {hitung }}$ dengan $t_{\text {tabel }}$ dan sig. hitung dengan $\alpha: 5 \%(0,05)$. Untuk variabel Struktur Modal berdasarkan $t_{\text {hitung }}$ diperoleh angka 2,506>1,992 dari $t_{\text {tabel }}$ dengan sig. hitung $0,014<0,05(\alpha: 5 \%)$, dengan 
demikian $\mathrm{H}_{2}$ diterima atau dengan kata lainvariabel Struktur Modal $\left(\mathrm{X}_{1}\right)$ berpengaruhterhadap nilai perusahaan (Y) BUMN di Indonesia. Untuk variabel Biaya Ekutitas berdasarkan $t_{\text {hitung }}$ diperoleh angka $0,045<1,992$ dari $t_{\text {tabel }}$ dengan sig. hitung 0,306 > 0,05 ( $\left.\alpha: 5 \%\right)$, dengan demikian $\mathrm{H}_{3}$ ditolak atau dengan kata lainvariabel Biaya Ekuitas $\left(\mathrm{X}_{2}\right)$ tidak berpengaruhterhadap nilai perusahaan (Y) BUMN di Indonesia. Sementara untuk variabel Kebijakan Dividen $\left(\mathrm{X}_{3}\right)$ dapat dilihat bahwa variabel independen tersebut tidak mempunyai pengaruh terhadap variabel nilai perusahaan (Y). Hal ini ditunjukan berdasarkan,Hasil uji statistik variabel Kebijakan Dividen $\left(X_{3}\right) t_{\text {hitung }}$ dan sig. hitung diperoleh angka $0,494<t_{\text {tabel }} 1,992$ dan sig. hitung 0,964>0,05 ( $\alpha$ : 5\%)dengan demikian $\mathrm{H}_{4}$ ditolak.

Berdasarkan hasil pengujian diatas, maka dapat dibuatpersamaan regresi sebagai berikut :

$$
Y=3,604-0,14 X_{1}-0,138 X_{2}+0,064 X_{3}
$$

Nilai konstan $(\mathrm{a})=3,604$. Nilai ini menunjukkan bahwa apabila tidak ada variabel Struktur Modal, Biaya Ekuitas, dan Kebijakan Dividen $\left(\mathrm{X}_{1}, \mathrm{X}_{2}\right.$, dan $\left.\mathrm{X}_{3}\right)$, maka nilai perusahaan akan naik sebesar 3,604 kali. Dengan kata lain nilai perusahaan akan naik sebesar 3,604 kali sebelum atau tanpa adanya variabel Struktur Modal, Biaya Ekuitas, dan Kebijakan Dividen $\left(X_{1}, X_{2}\right.$, dan $\left.X_{3}=0\right)$.

Nilai Struktur Modal/ $\mathrm{X}_{1}\left(\mathrm{~b}_{1}\right)=-0,14$. Nilai parameter atau koefisien regresi $\mathrm{b}_{1}$ ini menunjukkan bahwa setiap variabel Struktur Modal meningkat 1 kali, maka nilai perusahaan akan turun 0,14 kali dengan asumsi variabel lain tetap $\left(\mathrm{X}_{2}\right.$ dan $\left.\mathrm{X}_{3}\right)$ atau ceteris paribus.

\section{Pembahasan}

Hasil peneltian ini menunjukkan bahwa struktur modal berpengaruh secara negatif dan signifikan terhadap nilai perusahan yang dapat dilihat dari nilai koefisien regresi struktur modal sebesar $-0,14$ dengan signifikansi 0,014, yang berarti bahwa setiap adanya penurunan rasio DER sebagai proksi sumber pendanaan perusahaan sebesar 1 satuan akan berpengaruh pada peningkatan nilai perusahaan sebesar 0,14 satuan. Hasil temuan ini terbukti menerima hipotesis $2\left(\mathrm{H}_{2}\right)$ yang menyatakan bahwa struktur modal berpengaruh terhadap nilai perusahaan.

Hasil penelitian ini juga sesuai dengan Trade-off theory yang menyatakan bahwa terdapat struktur modal optimal yang dapat memaksimalkan atau berpengaruh terhadap nilai perusahaan.Namun dalam penelitian ini diduga perusahaan sudah melewati batas titik strutur modal yang optimal sehingga tidak lagi meningkatkan nilai perusahaan namun penggunaan hutang sebagai bagian dari rasio DER sudah menurunkan nilai perusahaan. Hal ini berdasarkan data bahwa rata-rata penggunaan hutang perusahaan BUMN perioe 2009-2014 yang ditunjuk oleh rasio DER untuk sampel 13 perusahaan yakni sebesar 3,62. Tingginya rasio hutang tersebut dimungkinkan karena keadaan ekonomi yang masih terpengaruh oleh krisis ekonomi global tahun 2008, dimana perusahaan lebih memilih untuk memakai sumber pendanaan yang berasal dari hutang daripada dengan penerbitan ekuitas dalam bentuk saham baru.

Hasil penelitian ini menunjukkan bahwa Biaya Ekuitas berpengaruh negatif namun tidak signifikan terhadap nilai perusahaan, yang dapat dilihat dari nilai koefisien regresi biaya ekuitas sebesar 0,138 dengan signifikansi 0,306, yang berarti bahwa setiap ada penurunan biaya ekuitas sebesar 1 satuan maka akan berpengaruh pada peningkatan nilai perusahan sebesar 0,138 satuan. Hasil temuan ini terbukti menolak hipotesis $3\left(\mathrm{H}_{3}\right)$ yang menyatakan bahwa biaya ekuitas berpengaruh terhadap nilai perusahaan

Hasil penelitian ini menunjukkan bahwa biaya ekuitas tidak berpengaruh terhadap nilai perusahaan. Ini berarti biaya ekuitas dipandang investor bukanlah suatu yang menggembirakan atau mengancam terhadap prospek perusahaan di masa yang akan datang.

Hasil penelitian ini menunjukkan bahwa kebijakan dividen berpengaruh positif namun tidak signifikan terhadap nilai perusahaan, yang dapat dilihat dari nilai koefisien regresi kebijakan dividen sebesar 0,064 dengan signifikansi 0,964 yang berarti bahwa setiap ada kenaikan kebijakan dividen sebesar 1 satuan maka akan berpengaruh pada peningkatan nilai perusahaan sebesar 0,064 satuan. Hasil temuan ini terbukti menolak hipotesis $4\left(\mathrm{H}_{4}\right)$ yang menyatakan bahwa kebijakan dividen berpengaruh terhadap nilai perusahaan.Hasil penelitian ini berarti sesuai dengan Dividend Irrelevance Theory yang menyatakan bahwa kebijakan dividen perusahan tidak mempunyai pengaruh terhadap nilai perusahaan.Kemakmuran pemegang saham dinilai tidak dipengaruhi oleh kebijakan dividen saat ini maupun di masa datang. 
Kesimpulan

Berdasarkan hasil analisis dan pembahasan dapat diambil beberapa kesimpulan sebagai berikut:

1. Hasil perhitungan pengujian yang dilakukan (Uji F) dapat dilihat variabel independen mempunyai pengaruh yang signifikan terhadap variabel dependen..

2. Hasil uji statistik variabel Struktur Modal (x1) menunjukkan bahwa struktur modal memiliki pengaruh negatif yang signifikan terhadap nilai perusahaan.

3. Hasil uji statistik variabel Biaya Ekuitas $\left(\mathrm{X}_{2}\right)$ tidak memiliki pengaruh signifikan terhadap nilai perusahaan.

4. Hasil uji statistik variabel Kebijakan Dividen $\left(\mathrm{X}_{3}\right)$ tidak memiliki pengaruh signifikan terhadap nilai perusahaan.

Saran

1. Bagi perusahaan, menemukan struktur modal yang dapat meningkatkan nilai dari perusahaan itu merupakan keharusan. Sesuai penelitian ini perusahaan disarankan untuk memperhatikan hal yang terkait dengan pemilihan sumber pendanaan untuk aktivitas bisnisnya. Perusahaan diharapkan untuk lebih mempertimbangkan sumber pendanaan yang berasal dari modal ekuitas baik dari pemilik maupun investor modal dibandingkan dengan melakukan peminjaman dana dari pihak luar pihak luar perusahaan.

2. Bagi investor dan kreditor, hendaknya dalam melakukan investasi maupun peminjaman dapat mempertimbangkan struktur modal yang dimiliki oleh perusahaan. Hal ini perlu dipertimbangkan agar pihak investor maupun kreditor bisa memaksimalkan hasil dari naiknya nilai perusahaan dengan menerima return yang diharapkan

3. Untuk peneliti selanjutnya dapat menambahkan variabel lain seperti laba per lembar saham, pendapatan perusahaan, dan perubahan nilai valuta asing yang dinilai dapat mempengaruhi nilai perusahaan.

\section{Daftar Pustaka}

Brigham, E. \& Houston, J. 2007.Fundamental of Financial Management $11^{\text {th }}$ Edition.USA: Thomson South-Western.

Bungin, Burhan. H.M. 2011.Metodologi Penelitian Kuantitatif.Jakarta: Kencana Prenada Media Group

Chen, J. \& Strange R. 2005.The Determinants of Capital Structure: Evidence from Chinese Listed Companies. Journal: Economic Change and Restructring

Darminto \& Manurung, A., H. 2008.Pengujian Teori Trade-Off dan Pecing Order dengan Satu Model

Dinamis pada Perusahaan Publik di Indonesia.Jurnal Manajemen Bisnis Vol 1. No.1

Collins, S., Filibus I., Clement, A. 2012.Corporate Capital Structure and Corporate Market Value: Empirical Evidence from Nigeria. International Journal of Economic and Finance: Canadian Center of Science and Education

Efendi, Andri S. 2013. Analisis Pengaruh Struktur Kepemilikan, Kebijakan Dividen dan Kebijakan Hutang terhadap Nilai Perusahaan dengan Variabel Kontrol Ukuran Perusahan, Pertumbuhan Perusahaan dan Kinerja Perusahaan.Semarang: Universitas Diponegoro

Ellisya, L., K. 2013. Analisis Faktor-Faktor yang Mempengaruhi Kebijakan Dividen Tunai.Lampung: Universitas Negeri Lampung

Fahmi, I. 2011. Analisis Kinerja Keuangan, Panduan bagi Akademisi, Manajer, dan Investor untuk Menilai dan Menganalisis Bisnis dari Aspek Keuangan. Bandung: Alfabeta

Hasan, et. al. 2014.Influence of Capital Structure on Firm Performance: Evidence from Bangladesh. Australia: University of Sydney

Indriantoro N., dan Supomo B. 2009. Metodologi Penelitian Bisnis Untuk Akuntansi dan Manajemen. Yogyakarta: BPFE-Yogyakarta

Jusriani, Ika F. 2013. Analisis Pengaruh Profitabilitas, Kebijakan Dividen, Kebijaan Utang, dan Kepemilikan Manajerial terhadap Nilai Perusahaan. Semarang: Universitas Diponegoro Semarang 
Kakansing, W. 2011.Metodologi Penelitian. Malang: Wineka Media

Nasution, Budi. 2009. Pengaruh Struktur Modal, Biaya Ekuitas (Cost Of Equity) dan Pertumbuhan Perusahaan terhdap Nilai Perusahaan dengan Klasifikasi Perusahan dan Kepemilikan Asing Sebagai Variabel Moderating pada Perusahaan Lembaga Keuangan yang Terdaftar di BEI. Medan: Universitas Sumatera Utara

Okiro, K., Aduda, J., Omoro, N. 2015. The Effect of Corporate Governance and Capital Structure on Performance of Firms Listed at The East African Community Securities Exchange. University Of Nairobi.European Scientific Journal March 2015 edition vol.11, No.7

Parrino, R., Kidwell D., Bates, T. 2012.Fundamental of Corporate Finance. United States of America: WIley

Patrick, O., Orinya O., Kemi A. 2013. The Impact of Capital Structure on Firm's Performance in Nigeria.St. Augustine College of Education.Munich Personal RePEc Archive (MPRA).

Peraturan Pemerintah Republik Indonesia Nomor 44 Tahun 2005. Tentang: Tata Cara Penyertaan dan Penatausahaan Modal Negara pada Badan Usaha Milik Negara dan Perseroan Terbatas

Prihadi, T. 2013. Capital Budgeting \& Fixed Asset Management. Jakarta: PPM

San, O., \& Heng T. 2011.Capital Structure and Corporate Performance of Malaysian Construction

Sector. University Putra Malaysia.International Journal of Humanities and Social Science Vol. 1 No. 2

Safrida, E. 2008.Pengaruh Struktur Modal dan Pertumbuhan Perusahaan terhadap Nilai Perusahaan pada Perusahaan Manufaktur di Bursa Efek Jakarta.Medan: Universitas Sumatera Utara

Subramanyam K.R \& Wild J.J. 2010.Analisis Laporan Keuangan. Jakarta: Salemba Empat

Sugihastuti. 2000. Bahasa Laporan Penelitian. Yogyakarta: Pustaka Belajar

Undang-Undang Republik Indonesia Nomor 3 Tahun 2015. Tentang: Perubahan atas Undang-Undang

Nomor 27 Tahun 2014 Tentang Anggaran Pendapatan dan Belanja Negara Tahun Angaran 2015

Van Horne, J., \& Wachowicz J. 2008.Fundamentals of Financial Management $13^{\text {th }}$ ed.Prentice Hall

Zalmi Zubir. 2011. Manajemen Portofolio Penerapannya dalam Investasi Saham. Jakarta: Salemba Empat 